\title{
Kompetensi dan Motivasi Kerja Terhadap Kesiapan Mahasiswa Jurusan Akuntansi dalam Menghadapi Era Revolusi Industri 4.0
}

\author{
A.A Ngurah Bagus Wiradarma ${ }^{1}$ \\ Fakultas Ekonomi dan Bisnis \\ Universitas Udayana, Indonesia
}

\author{
Ni Luh Sari Widhiyani2 ${ }^{2}$ \\ Fakultas Ekonomi dan Bisnis \\ Universitas Udayana, Indonesia
}

Surel : gungguswira04@gmail.com

\section{ABSTRAK}

Tujuan penelitian ini adalah untuk mengetahui pengaruh kompetensi dan motivasi kerja terhadap kesiapan mahasiswa jurusan akuntansi dalam menghadapi era revolusi industri 4.0. Penelitian ini dilakukan di Fakultas Ekonomi dan Bisnis Universitas Udayana Program Studi Akuntansi. Jumlah sampel yang diambil sebanyak 167 mahasiswa. Teknik analisis data yang digunakan untuk menguji hipotesis penelitian adalah analisis regresi linear berganda. Berdasarkan hasil analisis ditemukan bahwa kompetensi dan motivasi kerja berpengaruh positif terhadap kesiapan mahasiswa. Hal ini menunjukkan bahwa semakin tinggi kompetensi dan motivasi kerja yang dimiliki mahasiswa maka mampu meningkatkan kesiapan mahasiswa dalam menghadapi dunia kerja di era revolusi industri 4.0. Hal ini membuktikan bahwa kesiapan mahasiswa dipengaruhi oleh kompetensi dan motivasi kerja yang sangat penting dimiliki oleh setiap profesi.

Kata Kunci: Kompetensi; Motivasi Kerja; Kesiapan Mahasiswa; Era Revolusi Industri 4.0.

\section{The Effect of Competence and Work Motivation on the Readiness of Accounting Department Students in Facing the Industrial Revolution Era 4.0}

\begin{abstract}
The purpose of this study was to determine the effect of competence and work motivation on the readiness of students majoring in accounting in facing the era of the industrial revolution 4.0. This research was conducted at the Faculty of Economics and Business, Udayana University, Accounting Study Program. The number of samples taken was 167 students. The data analysis technique used to test the research hypothesis is multiple linear regression analysis. Based on the results of the analysis, it was found that competence and work motivation had a positive effect on student readiness. This shows that the higher the competence and work motivation of students, the higher the students' readiness to face the world of work in the era of the industrial revolution 4.0. This proves that student readiness is influenced by competence and work motivation which are very important for every profession.
\end{abstract}

Keywords: $\quad$ Competence; Motivation; Student Readiness; Industrial Revolution Era 4.0.

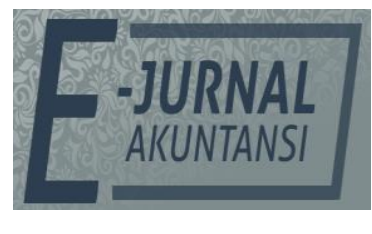

e-ISSN 2302-8556

Vol. 31 No. 2

Denpasar, Februari 2021

Hal. 337-348

DOI:

10.24843/EJA.2021.v31.i02.p06

PENGUTIPAN:

Wiradarma, A.A.N.B., \& Widhiyani, N.L.S. (2021).

Kompetensi dan Motivasi

Kerja Terhadap Kesiapan

Mahasiswa Jurusan Akuntansi dalam

Menghadapi Era Revolusi Industri 4.0. E-Jurnal Akuntansi, 31(2), 337-348

RIWAYAT ARTIKEL: Artikel Masuk:

24 Desember 2020 Artikel Diterima: 8 Februari 2021

Artikel dapat diakses : https://ojs.unud.ac.id/index.php/Akuntansi/index 


\section{PENDAHULUAN}

Era revolusi industri 4.0 ditandai dengan adanya perubahan yang signifikan dalam perkembangan akuntansi, dimana banyak orang dari berbagai latar belakang profesi khawatir akan hilangnya pekerjaan mereka karena munculnya teknologi yang canggih ini. Hal ini tentu tidak terlepas dari kehadiran revolusi industri 4.0 yang membawa peran mesin dan robot dalam melakukan pekerjaan. Industri 4.0 sebagai integrasi dari informasi digital dengan berbagai banyak sumber dan lokasi yang dimulai dari aktifitas manual dalam berbisnis menjadi lebih mudah dan efisien (Deloitte, 2018). Generasi keempat ini telah dirasakan bukan hanya di negara-negara maju yang memiliki modal dan ekonomi besar namun negara-negara di ASEAN yang memiliki peluang untuk mengembangkan aktivitas ekonomi dan kesejahteraan negaranya dalam revolusi ke empat ini. Pada era baru revolusi industri 4.0 dimulai pada tahun 2018 dengan adanya artificial intelligence, cloud computing, big data, sistem sensor dan otomasi, virtual augmented reality, mobility, dan internet of things (IoT) (Saraswati et al., 2020)

Direktur Jenderal Pembinaan Penempatan Tenaga Kerja dan Perluasan Kesempatan Kerja, Maruli Hasoloan pada liputan6.com Ramdhani, (2018) menyatakan bahwa mahasiswa yang tengah menuntut ilmu harus bersiap menghadapi tantangan besar yang terjadi saat ini. Tantangan ini dihadapi sesuai dengan pola kerja baru yang tercipta dalam era revolusi 4.0 yang dimana faktor pentingnya adalah keterampilan dan kompetensi yang harus ditingkatkan. Adanya tantangan dalam suatu permasalahan sebisa mungkin diselesaikan dengan solusi untuk mengatasi permasalahan yang ada seperti saat ini, dimana kondisi seperti ini merupakan tantangan baru bagi para mahasiswa yang akan menjadi lulusan perguruan tinggi untuk bersaing memenangkan persaingan dalam dunia kerja. Hal seperti ini berpengaruh langsung terhadap kompetensi yang harus dimiliki oleh para calon tenaga kerja (Wirianata, 2018). Perubahan pola baru ini membawa dampak terciptanya jabatan, keterampilan kerja baru dan hilangnya beberapa jabatan lama karena sudah tidak relevan lagi dalam dunia kerja. Tantangan itu harus dihadapi yang tercipta dalam revolusi indutri 4.0 sejumlah kompetensi baru dibutuhkan bagi para lulusan perguruan tinggi agar mampu menyesuaikan pola kerja diera revolusi industri 4.0. Pemahaman yang mendalam terkait motivasi kerja mahasiswa/i juga harus menjadi perhatian bagi para lulusan perguruan tinggi agar mereka memiliki kesiapan daya saing yang memadai.

Fenomena terbaru pada tahun 2020 ini sangat berbeda dari tahun sebelumnya dimana terdapat fenomena yang terjadi di seluruh penjuru dunia termasuk Indonesia yaitu virus covid-19. Virus ini mengakibatkan seluruh kegiatan berkumpul dengan jumlah yang banyak untuk tidak dilaksanakan dalam rangka meminimalisir penyebaran covid-19 di masyarakat. Kasus ini sangat berdampak bagi seluruh pekerja dan lembaga pendidikan di tingkat sekolah dasar, sekolah menengah pertama, sekolah menengah atas sampai ke perguruan tinggi. Dengan adanya himbauan untuk bekerja dan belajar dirumah maka semua lembaga pendidikan dan non pendidikan memanfaatkan perkembangan teknologi untuk bisa melakukan aktivitas dengan normal.

Era Revolusi Industri 4.0 bukan sekadar aplikasi teknologi canggih yang serba digital, melainkan juga memerlukan perubahan cara berpikir dan bekerja 
sehingga perlu penguasaan skill baru yang lebih adaptif terhadap situasi saat ini (Satria,2020). Covid-19 mempercepat kita beradaptasi dengan Era Revolusi Industri 4.0 dengan memanfaatkan teknologi digital. Memasuki era digital seperti sekarang ini teknologi sangat membantu untuk keperluan pendidikan seperti dosen dan mahasiswa karena sangat membantu proses kegiatan belajar dan mengajar. Penerapan kuliah online oleh perguruan tinggi patut di aspresiasi ditengah situasi melawan corona virus. Pada dunia kerja akibat dari adanya lockdown, beberapa perusahaan mengharuskan karyawannya untuk bekerja dari rumah (Work from Home). Kondisi Pandemi Covid-19 mempengaruhi sebagian besar proses bisnis yang dijalankan oleh KAP, baik itu manajemen internal, jaringan KAP, hingga perlunya pertimbangan kembali atas perikatan audit hingga pendekatan audit alternatif yang harus ditempuh dalam masa pandemi ini (Fatmasari, 2020). Kondisi seperti saat ini juga mempengaruhi auditor dalam memperoleh bukti audit dengan pemberlakuannya Pembatasan Sosial Berskala Besar (PSBB) dengan perubahan mengeksplorasi prosedur-prosedur audit alternatif untuk memperoleh bukti audit yang cukup dan tepat selama masa pandemi. Pada fenomena ini Lembaga pendidikan dan non pendidikan dituntut untuk menguasai teknologi informasi agar dapat meningkatkan kemampuan di bidang tekonologi agar mampu beradaptasi dengan perkembangan dunia.

The Association of American Colleges and Universities, sejak tahun 2007 Setiawan, (2019) menyatakan adanya kebutuhan generasi lulusan yang memiliki pengetahuan yang disiplin, high level skill, serta memiliki tanggung jawab sosial dan personal untuk menerapkan pengetahuan dalam menyelesaikan masalah yang kompleks. Untuk itu, perguruan tinggi harus bekerja sama dengan asosiasi profesi dan perusahaan untuk membuat revisi atas atribut yang dibutuhkan untuk para lulusan perguruan tinggi. Atribut tersebut meliputi pengetahuan dan keahlian memanfaatkan teknologi informasi dalam berpikir, metodologi dan prosedur kerja, kemampuan analitis serta pengetahuan terkait kemananan informasi.

Perguruan tinggi dapat bekerjasama dengan industri untuk meyakinkan bahwa para lulusan akan memiliki keahlian yang dibutuhkan pada era revolusi industri 4.0, seperti misalnya pemanfaatan teknologi berbasis AI dan big data (Crawford, 2015). Beberapa asosiasi dan perguruan tinggi di berbagai negara yang telah menerapkan perubahan ini yaitu (1) School Of Accounting at the Rawls College of Business, Texas Tech University menambahkan mata kuliah Big Data dan Dana Analitics ke dalam kurikulumnya. (2) St. Mary's University Greehey School of Business membentuk program sarjana accounting dan data analytics. (3) Chartered Institute Accountants of Sri Langka memasukkan topic Big Data dalam modul corporate level. (4) Malaysian Institute of Accountants mensyaratkan pendidikan akuntansi memasukkan topik IT, AIS, dan system analysis and design dalam kurikulum setiap perguruan tinggi (Gamage, 2016) .

Perkembangan teknologi informasi dibidang akuntansi diera revolusi industri 4.0 secara masif telah berlangsung mengikuti perkembangan zaman. Penggunaan akuntansi berbasis teknologi memberikan dampak efisiensi terhadap waktu, tenaga dan biaya. Selain itu, peningkatan efektifitas guna mendapatkan output laporan keuangan yang akurat dan tepat menjadi pemicu semakin berkembangnya penggunaan teknologi informasi di bidang akuntansi. 
Profesi akuntansi merupakan salah satu yang mengalami perkembangan yang sangat pesat yang dimana akuntansi telah menempati posisi yang semakin signifikan dalam fungsinya dimasyarakat industri modern. Akuntansi berperan sebagai pemberi informasi yang relevan dalam pengambilan keputusan, mengembangkan keputusan yang rasional dan menjaga organisasi tetap terkontrol (Burchell et al., 2005). Pemanfaatan teknologi informasi dalam akuntansi adalah efisien, penghematan waktu dan biaya serta meningkatkan efektifitas dan mencapai hasil laporan keuangan yang benar. Akuntan menunjukkan gelar profesional yang dapat diperoleh melalui pendidikan profesi akuntansi. Seorang akuntan berperan penting di seluruh bidang kerja, meliputi: akuntan publik, akuntan manajemen, akuntan sektor publik, serta akuntan pendidik. Seorang lulusan dalam profesi akuntansi tidak bekerja hanya sebagai penyedia informasi keuangan tetapi merupakan informasi non keuangan yang digunakan dalam pengambilan keputusan, Maka itu profesi akutansi memiliki kemampuan untuk memenuhi kebutuhan para pengguna informasi keuangan dan non keuangan sehingga memberikan nilai bagi masyarakat sekitar. Para akuntan pada generasi milenial ini harus memperkuat keahlian (mastering skills), membuka wawasan (opening mind), menanamkan nilai dan etika yang kuat (instilling strong values and ethics) untuk dapat bertahan menghadapi perubahan dan terus memberikan kontribusi terhadap peradaban (Nursyabila,2019).

Kata kunci untuk memenangkan persaingan dalam dunia kerja ditentukan oleh kompetensi dari para pencari kerja. Semakin seseorang memiliki kompetensi yang tinggi, maka peluangnya untuk memenangkan persaingan di dunia kerja juga akan semakin meningkat, karena merekalah orang-orang yang memiliki daya saing dan diminati oleh perusahaan (Aniswatin et al., 2020). Motivasi kerja akan mampu memberikan seseorang memiliki semangat, keinginan, kemauan yang tinggi serta akan memberikan kontribusi yang sebesar-besarnya demi keberhasilan dalam mencapai tujuan bersama (Sondang, 2018:138). Tantangan tersebut meliputi tersedianya sumber daya manusia terdidik, terlatih dan terampil yang memiliki daya saing di tingkat global (Muchsini, 2015).

Kompetensi dapat didefinisikan sebagai karakteristik dasar seseorang yang memiliki hubungan kausal dengan kriteria referensi efektivitas dan/atau keunggulan dalam pekerjaan atau situasi tertentu (Akhmad Syarifudin, 2014). Pada penelitian Puspitasari, (2019) menyatakan bahwa kompetensi sarjana akuntansi berpengaruh positif pada kemampuan daya saing. Hasil penelitian Saraswati et al., (2020), Hatta et al., (2016) dan Wirianata (2018) menyatakan bahwa kompetensi berpengaruh positif pada kesiapan mahasiswa. Kompetensi yang lebih tinggi mengharuskan mahasiswa/i untuk mencapai tingkat perkembangan kognitif yang lebih tinggi untuk memikirkan dan menggunakan pengetahuan yang diperoleh (Wolcott, 2010). Para pendidik akuntansi memberikan mahasiswa kompetensi yang dibutuhkan untuk berhasil, dengan memberdayakan semua lulusan akuntansi untuk memajukan profesi, organisasi, dan masyarakat mereka (Lawson et al., 2014). Wibowo (2007:324) menyatakan kompetensi adalah suatu kemampuan untuk melaksanakan atau melakukan suatu pekerjaan yang dilandasi atas keterampilan dan pengetahuan serta didukung oleh sikap kerja yang dituntut oleh pekerjaan tersebut. Yudistira \& Siwantara (2012) menyebutkan bahwa kompetensi berpengaruh positif dan signifikan secara langsung terhadap kinerja 
karyawan. Hal ini didukung oleh penelitian dari Sulistyaningsih (2009) bahwa kompetensi berpengaruh signifikan positif terhadap kinerja karyawan.

Faktor lain yang diduga mempengaruhi kesiapan mahasiswa jurusan akuntansi saat ini adalah motivasi kerja. Motivasi yang ada pada diri mahasiswa akan berpengaruh terhadap keberhasilan pencapaian tujuannya. Tujuan dari mahasiswa setelah lulus tidak lain yaitu untuk masuk ke dunia kerja. Hasil penelitian Aniswatin et al., (2020) menyatakan bahwa motivasi kerja berpengaruh positif terhadap kesiapan kerja mahasiswa. Hasil penelitiannya Yamsih et al., (2016) dan Yusman et al., (2019) juga menyatakan bahwa motivasi kerja berpengaruh positif terhadap kesiapan kerja siswa. Dalam hal motivasi kerja, dengan adanya motivasi kerja yang tinggi, mahasiswa akan mempunyai dorongan untuk bisa mencapai tujuannya. Dorongan tersebut membuat mahasiswa aktif untuk berlatih mempersiapkan diri memenuhi kriteria-kriteria yang diperlukan oleh dunia kerja. Sukardi (1993) menyatakan bahwa motivasi merupakan salah satu faktor yang mempengaruhi kesiapan kerja seseorang. Sejalan dengan hal tersebut, Soemanto (2012) juga menyatakan bahwa motivasi merupakan salah satu faktor yang membentuk kesiapan seseorang.

Kompetensi adalah serangkaian tindakan dengan penuh rasa tanggungjawab yang harus dipunyai seseorang sebagai persyaratan untuk dapat dikatakan berhasil dalam melaksanakan tugasnya (Yasin, 2011). Kemampuan untuk melaksanakan atau melakukan suatu pekerjaan yang dilandasi atas keterampilan dan pengetahuan serta didukung oleh sikap kerja yang dituntut oleh pekerjaan tersebut. Teori atribusi menjelaskan bahwa penyebab perilaku seseorang ditunjukkan dalam dispositional attributions dan situasional attributions. Dispositional atributions merupakan penyebab internal yang menunjuk pada aspek perilaku individual yang ada dalam diri seseorang dengan kepribadian, persepsi diri, kemampuan, dan motivasi. Penggunaan teori atribusi dalam hipotesis ini untuk mengetahui perilaku individu di perusahaan dalam bentuk internal seperti pengaruh kompetensi pada kesiapan mahasiswa.

Hasil penelitian yang dilakukan Puspitasari (2019) menyatakan bahwa kompetensi sarjana akuntansi berpengaruh positif pada kemampuan daya saing. Hasil penelitian ini sejalan dengan penelitian Saraswati et al., (2020), Hatta et al., (2016) dan Wirianata (2018) yang menyatakan bahwa kompetensi berpengaruh positif pada kesiapan mahasiswa.

$\mathrm{H}_{1}$ : Kompetensi berpengaruh positif pada Kesiapan Mahasiswa.

Motivasi kerja merupakan suatu dorongan dan keinginan yang berpengaruh membangkitkan, mengarahkan dan memelihara perilaku yang berhubungan dengan lingkungan kerja baik yang berasal dari dalam diri sendiri maupun dari luar dirinya. Teori atribusi menjelaskan bahwa penyebab perilaku seseorang ditunjukkan dalam dispositional attributions dan situasional attributions. Dispositional atributions merupakan penyebab internal yang menunjuk pada aspek perilaku individual yang ada dalam diri seseorang dengan kepribadian, persepsi diri, kemampuan, dan motivasi. Penggunaan teori atribusi dalam hipotesis ini untuk mengetahui perilaku individu di perusahaan dalam bentuk internal seperti pengaruh motivasi kerja pada kesiapan mahasiswa.

Hasil penelitian yang dilakukan Aniswatin et al., (2020) menyatakan bahwa motivasi kerja berpengaruh positif terhadap kesiapan kerja mahasiswa. Penelitian 
ini sejalan dengan penelitiannya Yamsih et al., (2016) dan Yusman et al., (2019) yang menyatakan bahwa motivasi kerja berpengaruh positif terhadap kesiapan kerja siswa.

$\mathrm{H}_{2}$ : Motivasi kerja berpengaruh positif pada kesiapan mahasiswa

\section{METODE PENELITIAN}

Penelitian ini dilakukan di Fakultas Ekonomi dan Bisnis Universitas Udayana dengan responden dari mahasiswa/i aktif angkatan 2017 Program Studi akuntansi untuk mengetahui kompetensi dan motivasi kerja yang dimiliki mahasiswa/i dalam menghadapi era revolusi industri 4.0.

Populasi dalam penelitian ini adalah seluruh mahasiswa aktif angkatan 2017 Program Studi Akuntansi di Fakultas Ekonomi dan Bisnis Universitas Udayana. Metode penentuan sampel dalam penelitian ini menggunakan non probability sampling, dengan jenis yang digunakan adalah propotionate stratified random sampling dengan cara mengambil subjek bukan berdasarkan strata, random, atau daerah tetapi didasarkan atas adanya tujuan tertentu Adapun perhitungan penentuan sampel dengan tingkat kesalahan sampel (Sampling error) sebesar 10\%. Penentuan jumlah sampel pada penelitian ini menggunakan rumus slovin sebagai formula untuk menghitung jumlah sampel, yaitu sebagai berikut.

$$
n=\frac{N}{1+N e^{2}}
$$

Keterangan :

$\mathrm{n}=$ Jumlah sampel yang diperlukan

$\mathrm{N}=$ Jumlah Populasi

$\mathrm{e}=$ error margin

Adapun perhitungan penentuan sampel dengan tingkat kesalahan sampel (Sampling error) sebesar 10\% adalah sebagai berikut.

$$
\begin{aligned}
& n=\frac{287}{1+(287)(0,05)^{2}} \\
& n=167,103 / 167
\end{aligned}
$$

Maka sampel yang akan diambil untuk pengujian penelitian ini adalah 167 sampel yang didistribusikan secara merata. Teknik analisis data yang digunakan dalam penelitian ini adalah analisis regresi linear berganda dengan menggunakan program Statistical Product and Service Solution (SPSS). Model regresi linier berganda ditunjukkan dalam persamaan sebagai berikut.

$$
Y=\alpha+\beta_{1} X_{1}+\beta_{2} X_{2}+\varepsilon
$$

Keterangan:

$$
\begin{array}{ll}
\mathrm{Y} & =\text { Kesiapan Mahasiswa } \\
\mathrm{a} & =\text { Konstanta } \\
\beta_{1,2} & =\text { Koefisien Regresi dari Variabel Independen } \\
\mathrm{X}_{1} & =\text { Kompetensi } \\
\mathrm{X}_{2} & =\text { Motivasi Kerja } \\
\varepsilon & =\text { Residual Error }
\end{array}
$$




\section{HASIL DAN PEMBAHASAN}

Statistik deskriptif yang disajikan dalam penelitian ini adalah untuk memberikan informasi mengenai karakteristik variabel penelitian. Karakteristik dalam penelitian ini terdiri atas jumlah pengamatan, nilai minimum, nilai maksimum, nilai mean, dan standar deviasi. Hasil statistik deskriptif pada penelitian ini dapat dilihat pada Tabel 1, sebagai berikut.

Tabel 1. Hasil Statistik Deskriptif

\begin{tabular}{llllll}
\hline Variabel & $\mathrm{N}$ & Min & Max & Mean & Std Deviation \\
\hline Kompetensi (X1) & 167 & 24,00 & 48,00 & 39,16 & 5,32025 \\
Motivasi Kerja (X2) & 167 & 11,00 & 28,00 & 23,31 & 3,33129 \\
Kesiapan Kerja (Y) & 167 & 8,00 & 20,00 & 16,02 & 2,43079 \\
\hline
\end{tabular}

Sumber: Data Penelitian, 2020

Kompetensi $\left(\mathrm{X}_{1}\right)$ memiliki nilai minimum sebesar 24,00 dan nilai maksimum sebesar 48,00. Mean atau nilai rata-rata kompetensi sebesar 39,16 yang menunjukkan bahwa respon responden cenderung memiliki kompetensi yang tinggi. Standar deviasi data tergolong homogen jika nilainya berada dibawah nilai rata-rata dan jika lebih besar dari dua kali nilai rata-rata data dapat dikatakan tergolong heterogen. Standar deviasi variabel kompetensi sebesar 5,32 yang berada dibawah nilai rata-rata sehingga dapat dikatakan data tidak bervariasi atau bersifat homogen.

Motivasi Kerja $\left(\mathrm{X}_{2}\right)$ memiliki nilai minimum sebesar 11,00 dan nilai maksimum sebesar 28,00. Mean atau nilai rata-rata motivasi kerja sebesar 23,31 yang menunjukkan bahwa respon responden cenderung memiliki motivasi kerja yang tinggi. Standar deviasi data tergolong homogen jika nilainya berada dibawah nilai rata-rata dan jika lebih besar dari dua kali nilai rata-rata data dapat dikatakan tergolong heterogen. Standar deviasi variabel motivasi kerja sebesar 3,33 yang berada dibawah nilai rata-rata sehingga dapat dikatakan data tidak bervariasi atau bersifat homogen.

Kesiapan Kerja (Y) memiliki nilai minimum sebesar 9,00 dan nilai maksimum sebesar 20,00. Mean atau nilai rata-rata kesiapan kerja sebesar 16,02 yang menunjukkan bahwa respon responden cenderung memiliki kesiapan kerja yang tinggi. Standar deviasi data tergolong homogen jika nilainya berada dibawah nilai rata-rata dan jika lebih besar dari dua kali nilai rata-rata data dapat dikatakan tergolong heterogen. Standar deviasi variabel kesiapan kerja sebesar 2,43 yang berada dibawah nilai rata-rata sehingga dapat dikatakan data tidak bervariasi atau bersifat homogen.

Tabel 2. Hasil Uji Regresi Linear Berganda

\begin{tabular}{llllrr}
\hline \multirow{2}{*}{ Variabel } & \multicolumn{3}{c}{$\begin{array}{c}\text { Unstandardized } \\
\text { Coefficients }\end{array}$} & $\begin{array}{c}\text { Standardized } \\
\text { Coefficients }\end{array}$ & \\
\cline { 2 - 4 } & \multicolumn{1}{c}{$\mathrm{B}$} & \multicolumn{1}{c}{ Std. Error } & Beta & $\mathrm{t}$ & Sig \\
\hline (Constant) & 1,376 & 1,010 & & 1,362 & 0,175 \\
Kompetensi $(X 1)$ & 0,201 & 0,030 & 0,441 & 6,797 & 0,000 \\
Motivasi Kerja(X2) & 0,29 & 0,047 & 0,398 & 6,133 & 0,000 \\
Adjust $R$ Square & 0,561 & & & \\
F Hitung & 106,934 & & & \\
F Sig & 0,000 & & & &
\end{tabular}


Berdasarkan informasi pada Tabel 2, menunjukkan nilai koefisien regresi dari variabel bebas kompetensi $\left(X_{1}\right)$, motivasi kerja $\left(X_{2}\right)$ dan nilai konstanta variabel terikat kesiapan mahasiswa $(Y)$, maka diperoleh persamaan regresi linear berganda sebagai berikut:

$$
\mathrm{Y}=1,376+0,201 \mathrm{X}_{1}+0,290 \mathrm{X}_{2}
$$

Nilai konstanta 1,376 menunjukkan bahwa apabila kompetensi dan motivasi kerja sama dengan nol ,maka kesiapan mahasiswa jurusan akuntansi dalam menghadapi dunia kerja era revolusi industri 4.0 akan mengalami peningkatan.

Nilai koefisien regresi $\left(\beta_{1}\right)$ kompetensi $\left(X_{1}\right)$ sebesar 0,201 berarti apabila kompetensi meningkat maka akan mengakibatkan peningkatan pada kesiapan mahasiswa dalam menghadapi dunia kerja era revolusi industri 4.0 dengan asumsi variabel lainnya konstan.

Nilai koefisien regresi $\left(\beta_{2}\right)$ motivasi kerja $\left(X_{2}\right)$ sebesar 0,290 berarti apabila motivasi kerja meningkat maka akan mengakibatkan peningkatan pada kesiapan mahasiswa jurusan akuntansi dalam menghadapi dunia kerja era revolusi industri 4.0 dengan asumsi variabel lainnya konstan.

Koefisien determinasi yang dihasilkan dari penelitian ini jika dilihat dari nilai Adjusted $R$ Square adalah sebesar 0,561. Adapun nilai hasil uji koefisien determinasi dapat dilihat pada Tabel 2, dapat digambarkan bahwa 56,1 persen kesiapan mahasiswa dapat dijelaskan oleh variabel kompetensi dan motivasi kerja. Sedangkan sisanya sebesar 43,9 persen kesiapan kerja mahasiswa jurusan akuntansi dipengaruhi oleh variabel lain diluar model regresi yang digunakan.

Uji kelayakan model (Uji F) bertujuan untuk menguji apakah model digunakan dalam penelitian ini layak atau tidak untuk digunakan sebagai alat analisis dalam menguji pengaruh variabel independen pada variabel dependennya. Berdasarkan hasil pengujian yang ditunjukkan pada Tabel 2, kelayakan model menunjukkan bahwa nilai uji F sebesar 106,934 dengan $p$-value (Sig.F) 0,000 lebih kecil dari nilai $a=0,05$. Hal ini menunjukkan bahwa model persamaan dalam penelitian ini layak untuk digunakan.

Nilai $\mathrm{t}$ hitung variabel kompetensi sebesar 6,797 sedangkan nilai $\mathrm{t}$ tabel sebesar 1,974 dan nilai signifikansi uji t yakni 0,000 lebih kecil dari $\alpha=0,05$ maka $\mathrm{H}_{0}$ ditolak. Hal ini berarti bahwa kompetensi berpengaruh positif signifikan pada kesiapan mahasiswa jurusan akuntansi dalam menghadapi dunia kerja era revolusi industri 4.0, sehingga hipotesis pertama dalam penelitian ini diterima.

Pengaruh kompetensi pada kesiapan mahasiswa jurusan akuntansi dalam menghadapi dunia kerja era revolusi industri 4.0 pada penelitian ini diuji dengan pembuktian hipotesis pertama dimana hasil yang diperoleh adalah hipotesis pertama diterima. Hasil ini menunjukkan bahwa variabel kompetensi berpengaruh positif pada kesiapan mahasiswa jurusan akuntansi dalam menghadapi dunia kerja era revolusi industri 4.0. Hasil ini menunjukkan bahwa semakin tinggi kompetensi yang dimiliki mahasiswa maka mampu meningkatkan kesiapan mahasiswa dalam menghadapi dunia kerja di era revolusi industri 4.0.

Berdasarkan hasil penelitian ini dapat disimpulkan bahwa mahasiswa jurusan akuntansi sudah siap menghadapi era revolusi industri 4.0 dengan kompetensi yang dimilikinya saat ini. Semakin baik kompetensi yang dimiliki mahasiswa/i jurusan akuntansi di Fakultas Ekonomi dan Bisnis Universitas 
Udayana maka akan semakin siap dalam menghadapi era revolusi industri 4.0. Sesuai dengan tuntutan pada era revolusi industri 4.0, mahasiswa/i harus memiliki kompetensi seperti pengetahuan (knowledge), keterampilan (skill), sikap (attitude) yang baik untuk mampu atau siap dalam memasuki dunia kerja.

Penelitian ini mengkonfirmasi mengenai Teori Atribusi yang menjelaskan bahwa penyebab perilaku seseorang ditunjukkan dalam dispositional attributions dan situasional attributions. Dispositional atributions merupakan penyebab internal yang menunjuk pada aspek perilaku individual yang ada dalam diri seseorang dengan kepribadian, persepsi diri, kemampuan, dan motivasi. Penggunaan teori atribusi dalam hipotesis ini untuk mengetahui perilaku individu di perusahaan dalam bentuk internal seperti pengaruh kompetensi pada kesiapan mahasiswa. Penelitian ini sejalan dengan penelitian Puspitasari (2019) menyatakan bahwa kompetensi sarjana akuntansi berpengaruh positif pada kemampuan daya saing. Hasil serupa dengan penelitian Saraswati et al., (2020), Hatta et al., (2016) dan Wirianata, (2018) yang menyatakan bahwa kompetensi berpengaruh positif pada kesiapan mahasiswa.

Nilai $t$ hitung variabel motivasi kerja sebesar 6,133 sedangkan nilai $t$ tabel sebesar 1,974 dan nilai signifikansi uji t yakni 0,000 lebih kecil dari $a=0,05$ maka $\mathrm{H}_{0}$ ditolak. Hal ini berarti bahwa motivasi kerja berpengaruh positif signifikan pada kesiapan mahasiswa jurusan akuntansi dalam menghadapi dunia kerja era revolusi industri 4.0, sehingga hipotesis kedua dalam penelitian ini diterima.

Pengaruh motivasi kerja pada kesiapan mahasiswa jurusan akuntansi dalam menghadapi dunia kerja era revolusi industri 4.0 pada penelitian ini diuji dengan pembuktian hipotesis kedua dimana hasil yang diperoleh adalah hipotesis kedua diterima. Hasil ini menunjukkan bahwa variabel motivasi kerja berpengaruh positif pada kesiapan mahasiswa jurusan akuntansi dalam menghadapi dunia kerja era revolusi industri 4.0. Hasil ini menunjukkan bahwa semakin tinggi motivasi kerja yang dimiliki mahasiswa maka mampu meningkatkan kesiapan mahasiswa dalam menghadapi dunia kerja di era revolusi industri 4.0.

Berdasarkan hasil penelitian ini dapat disimpulkan bahwa mahasiswa jurusan akuntansi sudah siap menghadapi era revolusi industri 4.0 dengan motivasi kerja yang dimilikinya saat ini. Semakin baik motivasi kerja yang dimiliki mahasiswa/i jurusan akuntansi di Fakultas Ekonomi dan Bisnis Universitas Udayana maka akan semakin siap dalam menghadapi era revolusi industri 4.0.

Penelitian ini mengkonfirmasi mengenai Teori Atribusi yang menjelaskan bahwa penyebab perilaku seseorang ditunjukkan dalam dispositional attributions dan situasional attributions. Dispositional atributions merupakan penyebab internal yang menunjuk pada aspek perilaku individual yang ada dalam diri seseorang dengan kepribadian, persepsi diri, kemampuan, dan motivasi. Penggunaan teori atribusi dalam hipotesis ini untuk mengetahui perilaku individu di perusahaan dalam bentuk internal seperti pengaruh motivasi kerja pada kesiapan mahasiswa. Penelitian ini sejalan dengan penelitian Aniswatin et al., (2020) yang menyatakan bahwa motivasi kerja berpengaruh positif terhadap kesiapan kerja mahasiswa. Penelitian ini serupa dengan penelitian Yamsih et al., (2016) dan Yusman et al., (2019) yang menyatakan bahwa motivasi kerja berpengaruh positif terhadap kesiapan kerja siswa. 


\section{SIMPULAN}

Penelitian ini mendukung Teori Atribusi yang menjelaskan bahwa penyebab perilaku seseorang ditunjukkan dalam dispositional atributions yang merupakan penyebab internal yang menunjuk pada aspek perilaku individual yang ada dalam diri seseorang dengan kepribadian, persepsi diri, kemampuan, dan motivasi. Penelitian ini membuktikan bahwa pengaruh kompetensi dan motivasi kerja pada kesiapan mahasiswa jurusan akuntansi dalam menghadapi dunia kerja era revolusi industri 4.0. Penelitian ini menemukan bahwa kesiapan mahasiswa jurusan akuntansi dipengaruhi oleh kompetensi dan motivasi kerja yang sangat penting untuk dimiliki oleh setiap profesi, karena dalam suatu pekerjaan yang dituntut untuk bekerja sesuai dengan tujuan dan memiliki kepercayaan dalam mengendalikan peristiwa-peristiwa terjadi pada tantangan dunia kerja era revolusi industri 4.0. Kompetensi dan motivasi kerja tersebut merupakan modal yang penting diterimanya mahasiswa/i di dunia kerja dan membuat mahasiswa/i lebih mudah beradaptasi dengan lingkungan pekerjaan. Secara praktis penelitian ini memberikan tambahan informasi tentang faktor yang dapat mempengaruhi kesiapan mahasiswa. Selain itu penelitian ini dapat digunakan bagi Lembaga Pendidikan untuk dapat mengembangkan kompetensi dan motivasi mahasiswa agar dapat menciptakan para lulusan perguruan tinggi dalam persaingan dunia kerja di era revolusi industri 4.0.

Penelitian selanjutnya juga dapat dilakukan dengan memperluas lingkup mahasiswa yang menjadi responden. Salah satunya adalah dengan mengambil responden mahasiswa jurusan akuntansi dari beberapa universitas yang ada di Bali. Selain itu, responden mahasiswa juga dapat dipilih dari mahasiswa di tiap angkatan untuk dapat melihat perbedaan tingkat kompetensi dan motivasi yang dimiliki mahasiswa/i dan tingkat kesiapan mereka dalam menghadapi dunia kerja era revolusi industri 4.0.

\section{REFERENSI}

Akhmad Syarifudin. (2014). Pengaruh Kompetensi SDM dan Peran Audit Intern terhadap Kualitas Laporan Keuangan Pemerintah Daerah dengan Variabel Intervening Sistem Pengendalian Internal Pemerintah (studi empiris pada Pemkab Kebumen) Akhmad Syarifudin. Jurnal Fokus Bisnis, Volume 14, No 02, Desember 2014, 14(25), 26-44.

Aniswatin, Afifudin, \& Junaidi. (2020). Persepsi Mahasiswa Akuntansi Tentang Keilmuan Akuntansi dan Soft Skill (Bahasa Inggris dan Teknolosi Informasi) Terhadap Kesiapan Menghadapi Tantangan Era Revolusi Industri 4.0. E-Jra, 09(02), 47-57.

Burchell, S., Clubb, C., Hopwood, A. G., Hughes, J., \& Nahapiet, J. (2005). The Roles of Accounting in Organizations and Society. Accounting, the Social and the Political, 5(1), 5-12. https:/ / doi.org/10.1016/b978-008044725-4/50004-7

Crawford, D. (2015). Prescribing an Accounting Curriculum: Shaping a New Vision for Accounting Education: Certified Public Accountant. The CPA Journal, 85(11), 6-9.

Deloitte. (2018). The fourth industrial revolution is here: Are you ready? Deloitte Insight, 1-26. https:/ / doi.org/10.1016/j.jbusres.2015.10.029 
Fatmasari,Ayu.(2020).Bagaimana Seharusnya Auditor Merespons Dampak Pandemi Covid-19 Terhadap Audit. Retrieved from https:/ / setjen.kemenkeu.go.id/

Gamage, P. (2016). Big Data: are accounting educators ready? Journal of Accounting and Management Information Systems, 15(3), 588-604.

Hatta, M., Auditya, L., dan Haris, M. (2016) "Pengaruh Kompetensi Terhadap Kesiapan Mahasiswa Jurusan Akuntansi Dalam Menghadapi Masyarakat Ekonomi ASEAN". Simposium Nasional Akuntansi XIX. Lampung.

Lawson, R. A., Blocher, E. J., Brewer, P. C., Cokins, G., Sorensen, J. E., Stout, D. E., Sundem, G. L., Wolcott, S. K., \& Wouters, M. J. F. (2014). Focusing accounting curricula on students' long-run careers: Recommendations for an integrated competency-based framework for accounting education. Issues in Accounting Education, 29(2), 295-317. https://doi.org/10.2308/iace-50673

Muchsini, B. (2015). Prosiding Seminar Nasional Pendidikan Akuntansi Dan Keuangan. Membangun Daya Saing Bangsa, 2, 84-93.

Nursyabila, M. (2019). Profesi Akuntansi Terancam Punah_Ini yang Harus Dipersiapkan_Okezone News. Retrieved from https:/ / news.okezone.com/

Puspitasari, E. (2019). E-JRA Vol. 08 No. 01 Juni 2019 Fakultas Ekonomi dan Bisnis Universitas Islam Malang. 08(01), 1-14.

Ramdhani, G. (2018). Mahasiswa Harus Bersiap Hadapi Era Revolusi Industri 4.0. Retrieved from https:/ / www.liputan6.com/

Saraswati, A. A. S. D., Putri, I. G. A. M. A. D., Suprasto, H. B., \& Sari, M. M. R. (2020). Influence of competence and locus of control on readiness of accounting department students facing the world of work era industrial revolution 4.0. International Research Journal of Management, IT E Social Science, $7(4), 14-23$.

Satria, Arif. (2020). Covid-19 dan RI 4.0. Retrieved from https:/ / www.republika.id.

Setiawan, A. (2019). Akuntansi 4.0: Membayangkan Pendidikan Akuntansi Dalam Era Revolusi Industri 4.0 Dengan Systems Thinking. Naskah Orasi Ilmiah, 116.

Soemanto, Wasty. 2012. Psikologi Pendidikan Landasan Kerja Pemimpin Indonesia. PT. Rineka Cipta.

Sondang P, Siagian. 2018. Manajemen Sumber Daya Manusia. Jakarta: Bumi Aksara.

Sukardi, Dewa Ketut. 1993. Bimbingan Karir di Sekolah-Sekolah. Jakarta:GI

Sulistyaningsih, A. (2009). Analisis Pengaruh Kepemimpinan , Kompetensi , Dan Penerapan Teknologi Informasi Dinas Pendidikan Kabupaten Klaten Oleh: Agustini Sulistyaningsih Stie - Aub Surakarta. 2009, 1(1), 1-25.

Wibowo. 2007. Manajemen Kinerja Edisi Ketiga. Jakarta; Rajawali Pers

Wirianata, H. (2018). Kompetensi Mahasiswa Jurusan Akuntansi Dan Kesiapannya Dalam Menghadapi Dunia Kerja Era Masyarakat Ekonomi Asean. January. https://doi.org/10.24912/je.v22i3.278

Wolcott, S. K. (2010). Professional Attributes: Teaching the Fine Arts of Being a 
Professional Accountant. Professional Attributes: Teaching the Fine Arts of Being a Professional Accountant, November, 1-18.

Yamsih, U., \& Khafid, M. (2016). Pengaruh Motivasi Kerja, Bimbingan Karier, Dan Prestasi Belajar Akuntansi Terhadap Kesiapan Kerja. Economic Education Analysis Journal, 5(3), 1010-1010.

Yasin, A. (2011). Pengembangan Kompetensi Pedagogik Guru Pendidikan Agama Islam Di Madrasah (Studi Kasus Di Min Malang I). El-Qudwah, 0(0), 157-181.

Yudistira, Cokorda Gede Putra. dan I Wayan Siwantara. 2012. Pengaruh Gaya Kepemimpinan Transformasional Ketua Koperasi dan Kompetensi Kecerdasan Emosional Manajer Koperasi Terhadap Kepuasan Kerja dan Kinerja Manajer Koperasi di Kabupaten Buleleng. Jurnal manajemen, Strategi Bisnis dan Kewirausahaan. (6):1 h: 99 -108. Yusman, I. Y., Ismiyati, I., \& Mar'atus Sholikah, M. (2019). Pengaruh OJT, Prestasi Belajar, Informasi Kerja, dan Motivasi Kerja Terhadap Kesiapan Kerja Siswa SMK. Efisiensi - Kajian Ilmu Administrasi, 16(1), 49-58. https://doi.org/10.21831/efisiensi.v16i1.24476 